\title{
Development of chitosan membranes for use in pem fuel cells
}
K. N. Lupatini ${ }^{1,2}$
L. S. N. Ellendersen ${ }^{1}$
J. V. Schaffer ${ }^{1}$
G. I. B. Muniz'
B. Machado'
R. J. Ferracin ${ }^{1,2}$
E. S. da Silva'
H. J. Alves ${ }^{1,2}$

\section{Abstract}

Membranes prepared with commercial chitosan and with chitosan extracted from carapaces of freshwater shrimp were developed to be tested as low cost electrolyte in PEM-FC fuel cells. The main factors of interest of this research are related to the possibility that the biopolymer might undergo physical and chemical modifications due to amine groups $\left(-\mathrm{NH}_{2}\right)$ existing in the structure. The shrimp carapaces were obtained from residues of shrimp farming in the West Region of Paraná - Brazil. Researches testing chitosan membranes as proton conductors usually apply matrices of other polymers together, forming composites with more suitable properties for this purpose. Very few studies investigate the effects of chitosan properties for obtaining these membranes and normally, membranes of commercial chitosan are utilized. In original research, it was investigated the influence of the degree of deacetylation (DDA) and the molar mass (Mv) of chitosan used in the preparation of membranes on the performance regarding proton conductivity and other properties. For obtaining chitosan and membranes, classical chemical methods were applied. The results indicate that chitosan produced in laboratory led to obtaining membranes with promising properties, presenting proton conductivity one hundred times higher when compared to those presented by commercial chitosan membranes, which are in order of 1,6 and $1,910^{-2}{\mathrm{~S} . \mathrm{cm}^{-1}}^{-}$. The significant increase in proton conductivity can be associated with the higher number and availability of $-\mathrm{NH}_{2}$ groups existent in chitosan with higher DDA and lower Mv, produced in laboratory. The versatility of chitosan and the possibility

1 Federal University of Paraná, Palotina, Paraná, Brazil.

2 State University of Paraná (UNIOESTE), Cascavel, Paraná, Brazil. 
of exploration and chemical modification of its structure make it attractive for development of proton-conducting polymer membranes with very similar performance when compared to the performance presented by Nafion®.

Keywords: Fuel cell, PEM, Proton conductivity, Materials for electrolyte.

\section{Introduction}

PEM fuel cells (PEMFC) stand out among the different technologies in development for generating energy in a sustainable and efficient manner. Although the energy market is a promising field for its use, it still has a high cost of production and maintenance, and employs materials that are derived from non-renewable sources, such is the case of PEM fuel cells which use as their main electrolyte a petroleum oil derivative, known as Nafion ${ }^{\circledR}[1,2]$.

The strong development of alternative and comparable materials to the commercial electrolyte mainly by using raw materials of low manufacturing cost and are capable of conducting protons.

A promising alternative is chitosan, a natural biopolymer consisting predominantly of 2-amino-2-deoxy-D-glucose and 2-acetamido-D-glucose (copolymer), derived from the N-deacetylation of chitin, found abundantly in the skeletal matrix of invertebrates, diatomaceous algae, cell walls of some fungi and the shells of some crustaceans.

Worldwide, shrimp farming activity produces about 4 million tons/year of environmentally liable waste, where $30 \%$ of it is rich in chitin, the precursor of chitosan. $[3,4]$

In an acidic medium, chitosan is soluble and becomes a type of polyelectrolyte carrier of positive charges due to the presence of amino groups which act as a Lewis base, being easily protonated $\left(-\mathrm{NH}_{3}{ }^{+}\right)$. What makes it even more interesting is the wide availability, low cost and the various possibilities of structural changes that facilitate the production of thin and resistant membranes [5,6].

There are numerous surveys conducted in the development of chitosan membranes. However, there are very few studies that investigate their individual properties.

\section{Objective}

This study aimed to investigate the influence of the degree of deacetylation (DDA) and molar mass (Mm) of chitosan obtained commercially and from a laboratory, used in the preparation of membranes and their performance in face 
of proton conductivity, exploring chemical properties of this material to obtain electrolytes with properties adequate to PEM fuel cells.

\section{Methods}

For the purpose of comparison, membranes were prepared with commercial chitosan (A) of average molar mass, obtained from Sigma-Aldrich.

\subsection{Chitosan obtaining}

Chitosan (B) was extracted from the exoskeletal chitin of freshwater shrimp Macrobrachium rosenbergii, derived from a shrimp farming facility in the city of Nova Santa Rosa, in the west of Paraná, Brazil. The shells were washed and dried at $60^{\circ} \mathrm{C}$, followed by milling in jars with porcelain balls and sieving through a sieve of $63 \mu \mathrm{m}$ of aperture. The material obtained was subjected to demineralization and deproteination through the method described by Tolaimate et al. (2003) [7].

The extracted chitin was subjected to deacetylation in a solution of $\mathrm{NaOH}$ $50 \%(\mathrm{~m} / \mathrm{v})$ in a proportion of $2.5 \%\left(\mathrm{~m} \mathrm{~V}^{-1}\right)$, in a reflux system for $10 \mathrm{~h}$ at $120{ }^{\circ} \mathrm{C}$. The chitosan obtained was then washed until reaching a neutral $\mathrm{pH}$ and dried in an oven for $24 \mathrm{~h}$ at $60^{\circ} \mathrm{C}$.

\subsection{Chitosan characterization}

To determine the degree of deacetylation (DDA) of the chitosan sample a conductometric titration was done using $200 \mathrm{mg}$ of biopolymer in a $40 \mathrm{~mL}$ hydrochloric acid solution of 0.05 mol. $\mathrm{L}^{-1}$, kept under orbital shaking for $18 \mathrm{~h}$ at 25 $\pm 0.1{ }^{\circ} \mathrm{C}$. The samples were titrated in a sodium hydroxide solution, $0.17 \mathrm{~mol} . \mathrm{L}^{-1}$, utilizing Equation 1 to determine the DDA (\%).

$$
\% \text { DDA }=\frac{16,1 \times[\text { base }] \times(\mathrm{V} 2-\mathrm{V} 1)}{\mathrm{m}}
$$

$\mathrm{V} 1$ is the volume ( $\mathrm{ml})$ of $\mathrm{NaOH}$ used for neutralizing the excess of $\mathrm{HCl}$; $\mathrm{V} 2$ is the volume $(\mathrm{ml})$ of $\mathrm{NaOH}$ required for neutralization of the acid groups $\left(-\mathrm{NH}_{3}{ }^{+}\right)$ of protonated chitosan; [Base] concentration (M) of $\mathrm{NaOH}$ used; and $m$ the mass of the chitosan sample added to the acidic solution. V1 and V2 were determined based on inflections observed in conductivity graphics $\left(\mu \mathrm{cm}^{-1}\right) \times \mathrm{NaOH}(\mathrm{ml})$ consumed [5].

The viscosimetric average molar mass was obtained by determining the flow time of the solvent and the diluted solutions of chitosan $\left(0,31\right.$ a $\left.0,73 \mathrm{mg} \cdot \mathrm{mL}^{-1}\right)$ in 0,3 M HAc/0,2 M NaAc, held in triplicate using a Ubbelohde viscometer with a 
glass capillary $(\varphi=0.44 \mathrm{~mm})$ immersed in a thermostated bath while maintaining the temperature at $25 \pm 0.1{ }^{\circ} \mathrm{C}$. The relation between the intrinsic viscosity [ $\left.\eta\right]$ (dL g-1) and the average viscosimetric molar mass of the $M m(\mathrm{Da})$ polymer was established by Equation 2 from Mark-Houwink-Sakurada [8].

$$
[\eta]=K \bar{M}_{V}^{\alpha}
$$

Being $\mathrm{K}$ and $\alpha$ constants for a given polymer-solvent system, which in the case of chitosan vary according to the DDA [9], as well as the molar mass range. In this case, for Chitosan $\mathrm{A}$ and $\mathrm{B}$, respectively, values $\mathrm{K}=0.074$ and $\alpha=0.76$ were adopted.

\subsection{Membrane obtaining}

To obtain the membranes $2.0 \mathrm{~g}$ of chitosan were dissolved in $150 \mathrm{ml}$ of $15 \%$ acetic acid $(\mathrm{v} / \mathrm{v})$ in a thermostated bath at $50^{\circ} \mathrm{C}$. Aliquots of the solution were transferred to silicone molds and oven dried at $60^{\circ} \mathrm{C}$ for $24 \mathrm{~h}$. The resulting membranes were neutralized in a $0.2 \mathrm{M} \mathrm{NaOH}$ solution for $30 \mathrm{~min}$ and then washed with distilled water until reaching a neutral $\mathrm{pH}$. Some membranes were crosslinked in a sulfuric acid solution at a concentration of 2.0 and $4.0 \mathrm{M}$ for 10 and 15 hours, followed by neutralization as described above, and stretched to dry at ambient conditions between 25 and $30^{\circ} \mathrm{C}$ for $24 \mathrm{~h} \mathrm{[2]} \mathrm{and} \mathrm{identified} \mathrm{as} \mathrm{by} \mathrm{Table} 1$.

Table 1 Identification of chitosan membranes A and B

\begin{tabular}{|l|l|l|l|l|}
\hline \multicolumn{2}{|c|}{ Membrane } & \multicolumn{1}{|c|}{$\begin{array}{c}\text { Chitosan } \mathrm{H}_{2} \mathrm{SO}_{4} \\
\text { (mol.L-1) }\end{array}$} & \multicolumn{2}{c|}{$\begin{array}{c}\text { Reticulation } \\
\text { Time (h) }\end{array}$} \\
\hline MQA01 & (b) & QA & 2 & 10 \\
\hline MQA02 & (c) & QA & 4 & 10 \\
\hline MQA03 & (d) & QA & 2 & 15 \\
\hline MQA04 & (e) & QA & 4 & 15 \\
\hline MQA05 & (a) & QA & 0 & 0 \\
\hline MQBO1 & (b) & QB & 2 & 10 \\
\hline MQBO2 & (c) & QB & 4 & 10 \\
\hline MQBO3 & (d) & QB & 2 & 15 \\
\hline MQBO4 & (e) & QB & 4 & 15 \\
\hline MQBO5 & (a) & QB & 0 & 0 \\
\hline
\end{tabular}




\subsection{Membrane characterization}

The membranes were analyzed in an available area of $5 \times 5 \mathrm{~cm}$, with the exception of the electrochemical impedance analysis, which was performed in $1 \mathrm{x} 1 \mathrm{~cm}$.

X-Ray Diffraction (XRD): the analyzes were carried out on a Shimadzu diffractometer, Model XRD-6000 in the range of $5^{\circ}<2 \theta<70^{\circ}$, with CuKa radiation $(\lambda=1.5406 \AA, 40 \mathrm{kV}, 30 \mathrm{~mA})$ and a continuous scan rate of $1.5^{\circ} \mathrm{min}^{-1}$ [9].

Water absorption: The water absorption coefficient was determined by the ratio between the mass of the dry and wet membrane according to Equation 3. The initial dry weight was determined by thermal treatment in an oven at $60^{\circ} \mathrm{C}$ for $24 \mathrm{~h}$. Subsequently, the membranes were hydrated at temperatures of 40 to $70^{\circ} \mathrm{C}$ for $1 \mathrm{~h}$, followed by removal of excess water and weighing [10].

$$
\Delta \mathbf{M}=\frac{\mathbf{M}_{\mathbf{u}}-\mathbf{M}_{\mathrm{s}}}{\mathbf{M}_{\mathrm{s}}} \times 100
$$

Since $\Delta \mathrm{M}$ is the coefficient of water absorption, $\mathrm{M}_{\mathrm{w}}$ is the wet mass of the membrane and $M_{d}$ the mass of the dried membrane. Protonic conductivity $\sigma$ $\underline{\left(S . \mathrm{cm}^{-1}\right)}$ was determined by Electrochemical impedance analysis in the testing station (RSI) described by Paganini, et al, (1997) [11], and potentiostat PGSTAT 30 AUTOLAB (Eco Chemie) fitted with a Frequency response analyzer (FRA). For this analysis the frequency varied between $1.0 \mathrm{MHz}$ to $0.1 \mathrm{~Hz}$ at temperatures of $25,40,60$ and $80{ }^{\circ} \mathrm{C}$ with hydrogen gas (prepurified $>99.95 \%$ ) and oxygen $(>90 \%$ ) humidified. The electrodes used were GDL (Gas Diffusion Layer) with $0.4 \mathrm{mg} \mathrm{cm}^{-2} \mathrm{Pt}$, with the commercial catalyst containing $30 \%$ in Pt weight on a high surface area carbon (Vulcan XC 72 ) and $0.87 \mathrm{mg} \mathrm{cm}^{-2}$ Nafion ${ }^{\circledR}$. The membrane resistance values were determined directly from the Nyquist diagrams in which the imaginary component $\left(Z_{\text {`>, }} y\right.$ axis) is drawn in relation to the real component $(Z$, $x$ axis) for each frequency with $Z$ > as the resistivity of the material $(\mathrm{R})$. The proton conductivity $(\sigma)$, given in $S \mathrm{~cm}^{-1}$, was determined according to Equation 4. [16].

$$
\sigma=\frac{1}{R} \cdot \frac{L}{A}
$$

Being L, A and R, respectively, the distance between the electrodes $(\mathrm{cm})$ the membrane area $\left(\mathrm{cm}^{2}\right)$ and electrical resistance $(\Omega)$.

Thickness: The thickness of the membrane, expressed in microns $(\mu \mathrm{m})$ is determined using a Mitutuyo digital micrometer with a sensitivity of $1 \mu \mathrm{m}$. Measurements of the samples were taken at 10 random points and the results were expressed as the average of measurements made in each sample [12]. 


\section{Results}

\subsection{Chitosan - DDA, Mm and XRD}

According to the conductometric titration curves of chitosan $\mathrm{A}$ and $\mathrm{B}$, the DDA calculated from Equation 1 was of $64.3 \pm 1.4 \%$ for chitosan A and $76.0 \pm$ $0.8 \%$ for $\mathrm{B}$.

The value set for average viscosimetric molar mass of chitosans, calculated from Equation 2, were from $220.8 \mathrm{kDa}$ chitosan $\mathrm{A}$ and $63.07 \mathrm{kDa}$ B.

In XRD, the major crystalline peaks of the samples are located at approximately $2 \theta=9^{\circ}$ and $20^{\circ}$.

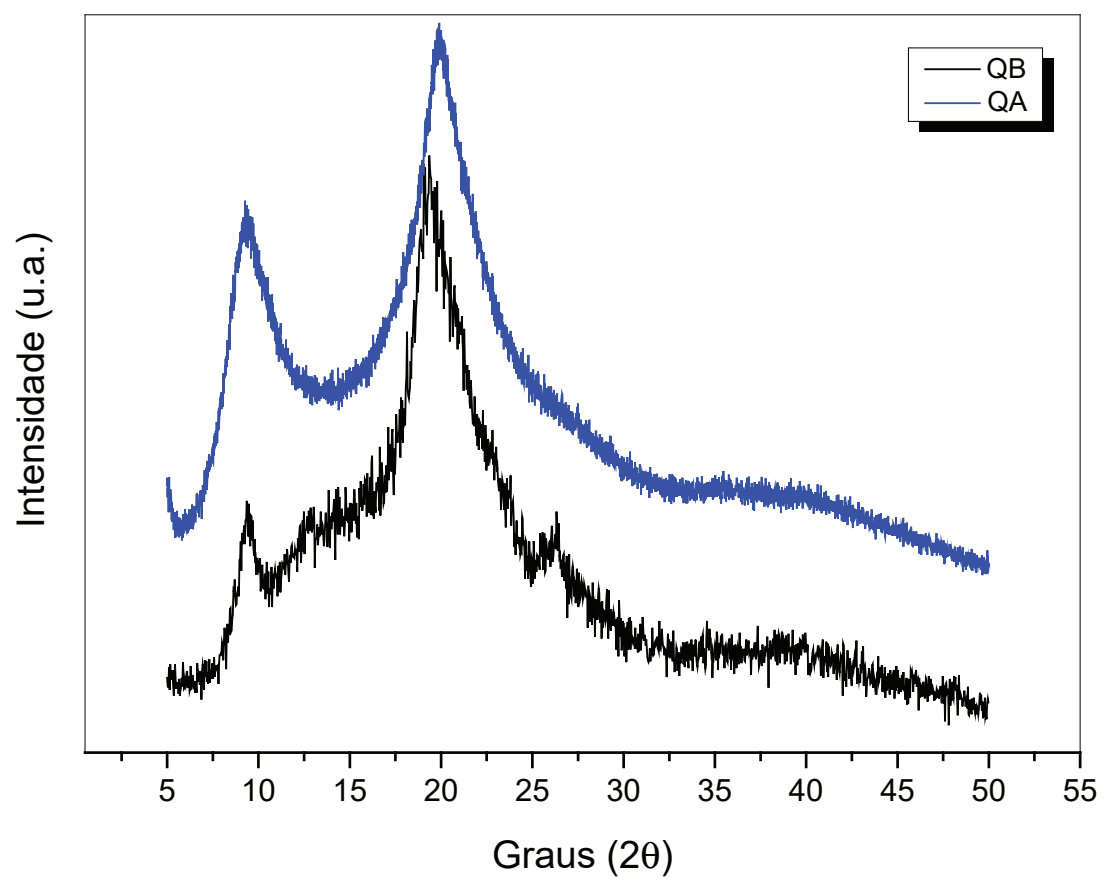

Figure 1 XRD patterns of the powdered chitosan samples (A) (QA) and B (QB).

Chitosan B had a greater DDA and lower Mm compared to chitosan A. These results allow us to affirm that the method used to obtain the same, resulted in more functional groups $\left(\mathrm{NH}_{3}{ }^{+}\right)$available to perform the protonic exchange as a membrane.

XRD analysis confirms the amorphous nature of chitosan $\mathrm{B}$, which was also observed by Arantes et al (2015) [13] where the crystalline peaks are less pronounced at $10^{\circ}$ and $20^{\circ}$. Aguiar et al., (2012) [14] stated that amorphous mate- 
rials are more interesting for application in PEMFC since they have much higher conductivity than semicrystalline materials.

\subsection{Membrane characterization}

\subsection{XRD}

According to the diffractogram of Figure 2 for the chitosan A membranes (CAM), a single broad band was observed in approximately $15-45^{\circ}$, wherein (a) and (b) exhibit strong reflections initiated between $9-10^{\circ}$ and 19 and $20^{\circ}$. The peaks observed in (d) were between $11^{\circ}$ and $20^{\circ}$, but with less intensity, with a slightly wider band than (a). In contrast, membrane (e) has a more apparent peak at $20^{\circ}$.

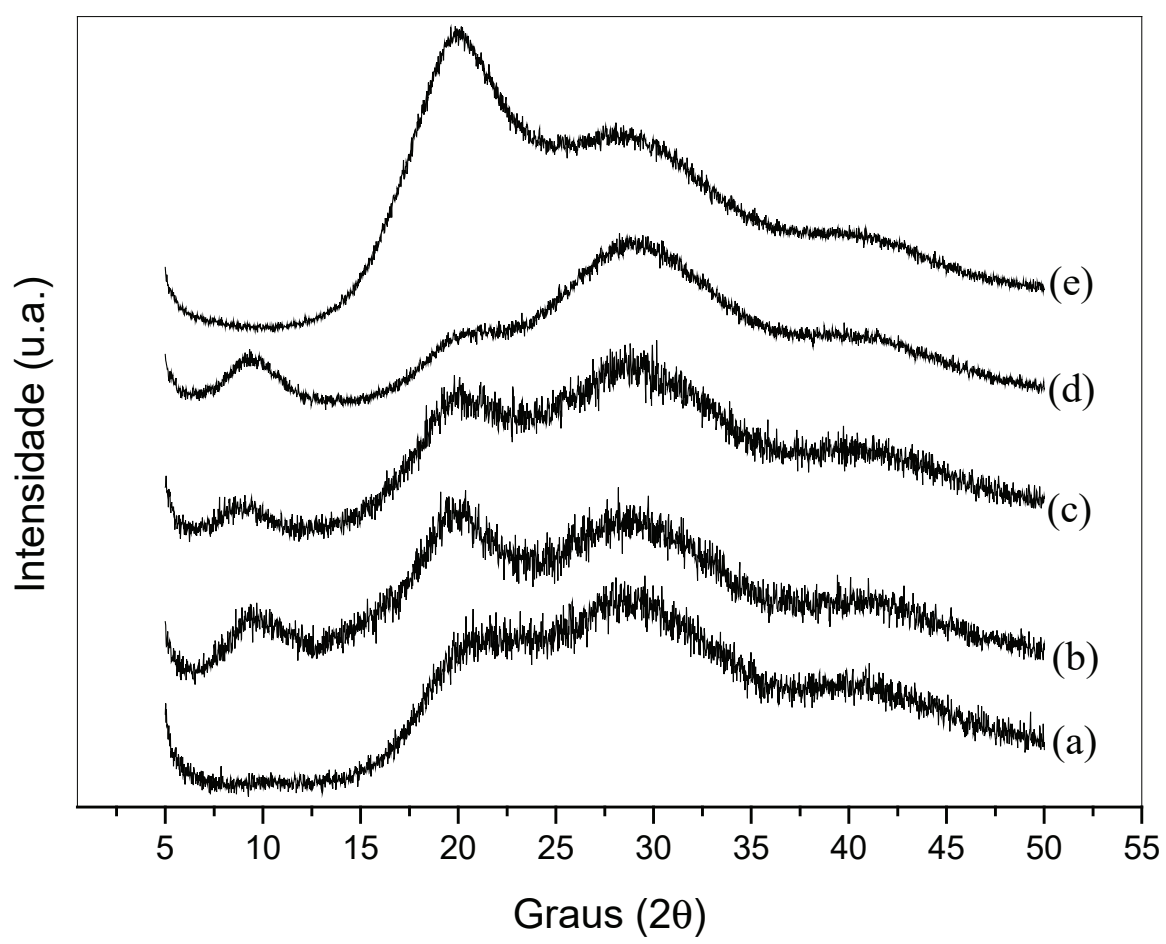

Figure 2 XRD patterns of Chitosan A membranes

The chitosan $\mathrm{B}$ membranes showed broad bands between 18 and $45^{\circ}$, as observed in Figure 3. 


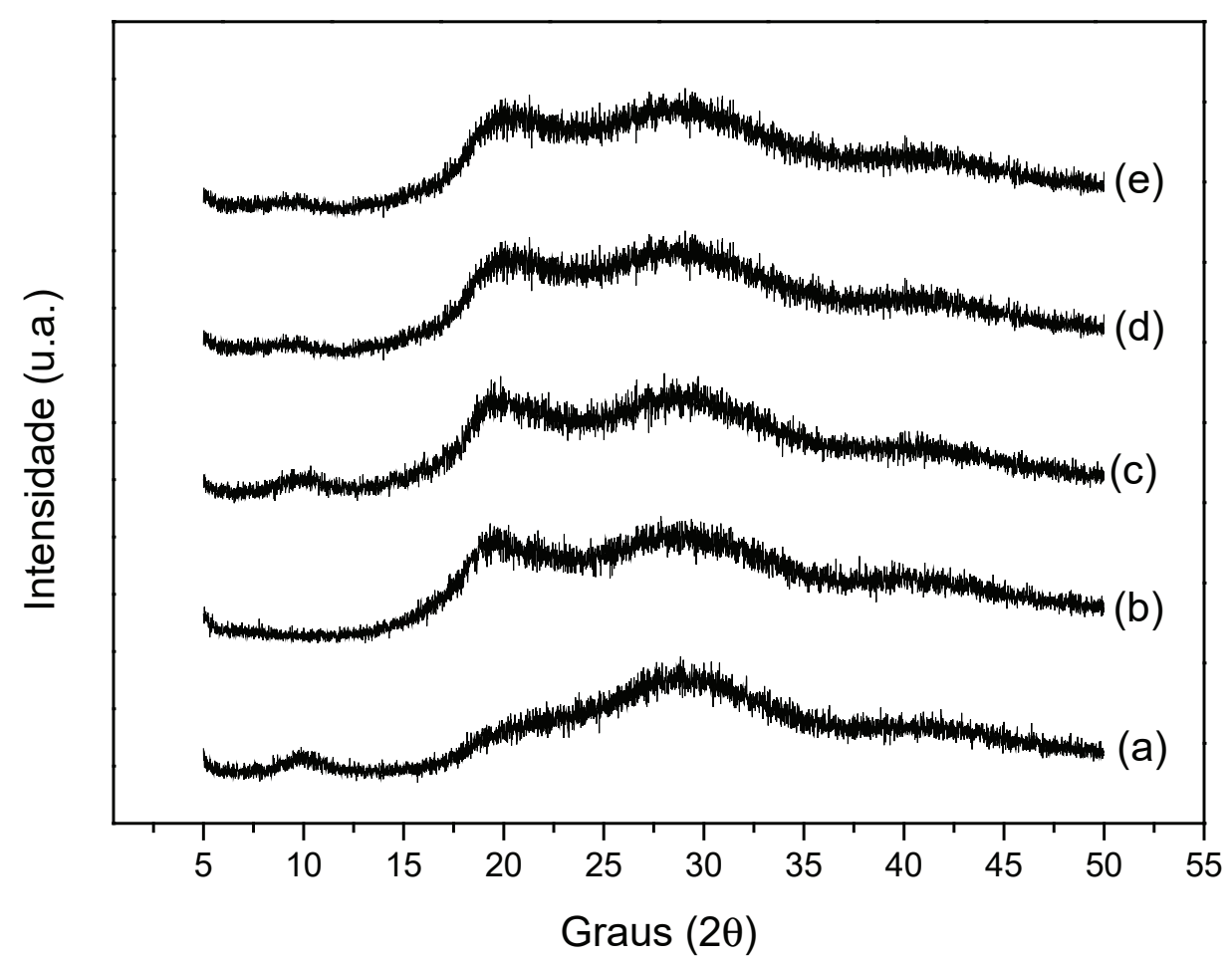

Figure 3 XRD patterns of Chitosan B membranes

The XRD patterns of the membranes showed amorphous character, distinct from the powdered chitosan samples. The characteristic chitosan A peaks, seen in Figure 2, were also found in the diffractograms of chitosan membranes presented by Lima (2010) [15] Signini and Campana-Son (2001) [16].

In the diffractograms of MQBs there is a clear reduction of the intensity of the peaks characteristic of chitosan B, with the bands shown in Figure 3 visually wider than those obtained for MQAs, which according to Aguiar et al., (2012) [14] favors their use as electrolyte PEMFC since amorphous structures tend to higher protonic conductivity.

The effect of crosslinking of the polymeric chains of the membranes is not clear, since these are similar to the membranes without crosslinking.

\subsubsection{Water absorption}

The coefficient of water absorption for chitosan A and B membranes can be seen in Figures 4 and 5, respectively. 


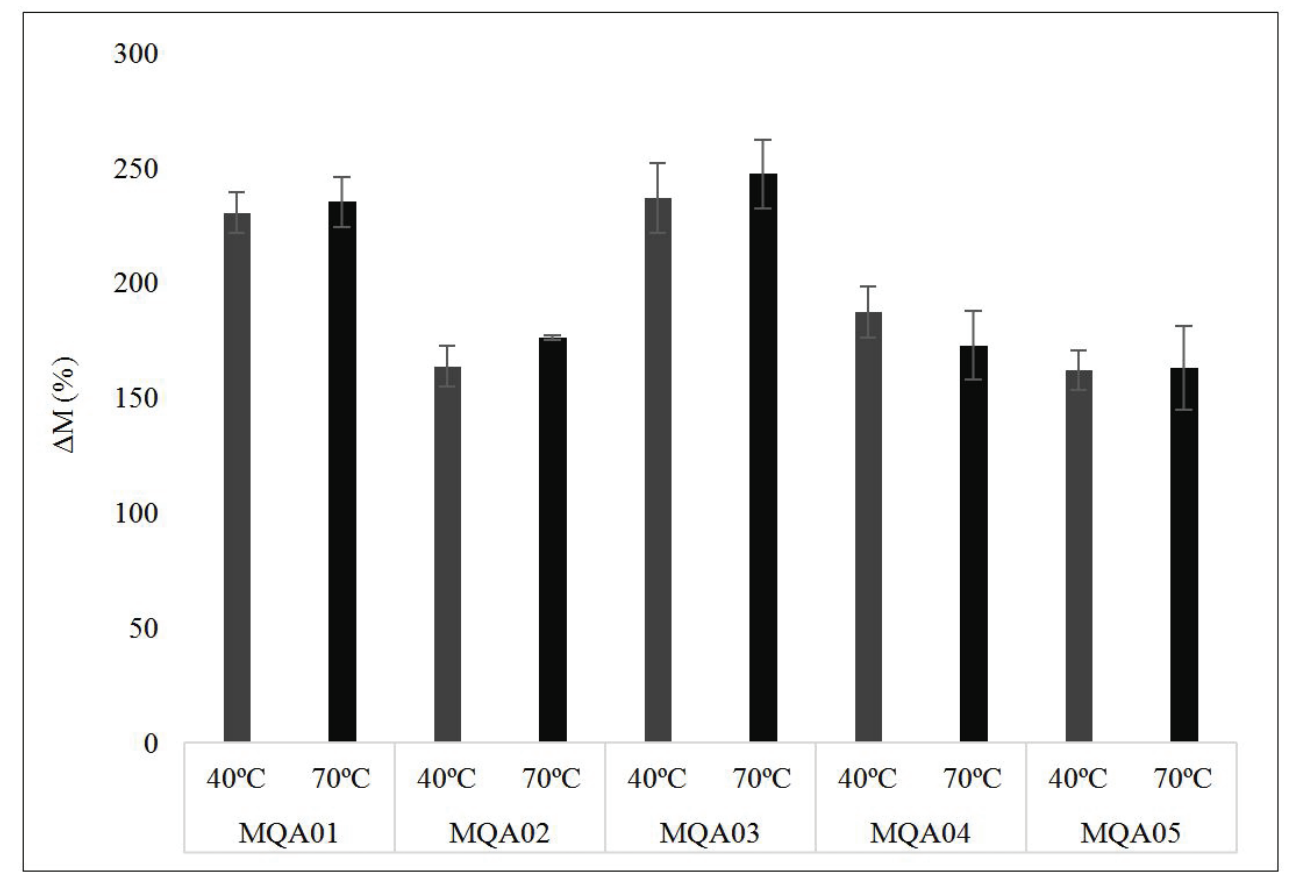

Figure 4 Water Absorption of chitosan A membranes

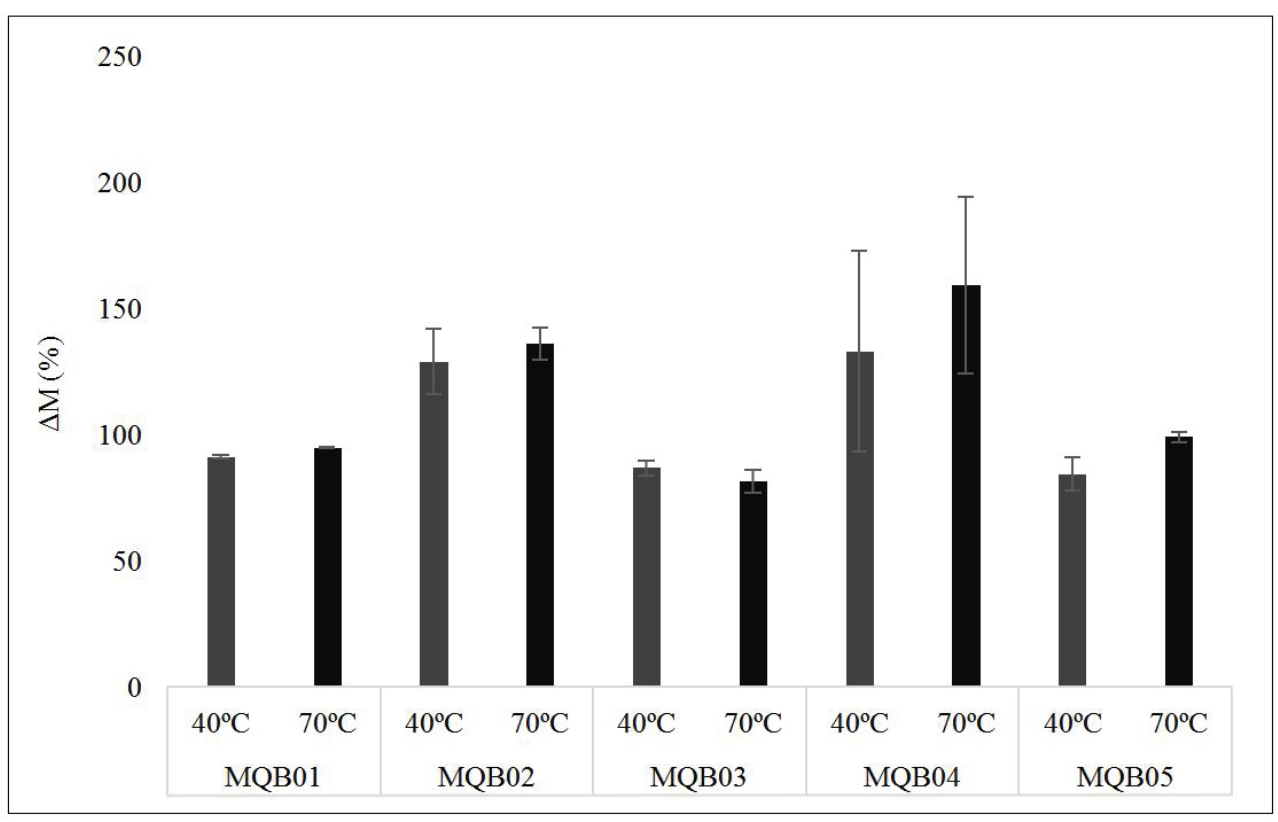

Figure 5 Water Absorption of chitosan A membranes 
According to Smitha et al., (2008) [2], the cross-links between the chains of chitosan, from crosslinking may restrict the entry of water molecules within the membrane. This effect can be observed in the membranes of the MQB series, which had lower water absorption compared to MQA, once crosslinking occurs more effectively in chitosan membranes with high DDA.

However, when comparing the membranes of the same series, it is noted that the uncrosslinked showed lower absorption coefficient compared to the crosslinked. This behavior can be explained by the interaction of the sulfonate groups of the crosslinking agent $\left(\mathrm{SO}_{4}{ }^{2-}\right)$ and the protonated groups $\left(-\mathrm{NH}_{3}{ }^{+}\right)$of the chitosan chains of the crosslinked membranes, which causes morphological changes in the membrane, reducing its crystalline domains, making it hydrophilic [2].

The temperature effect was also observed, as described by Perles (2008) [17] where its increase caused the expansion of the pores and channels of the membrane, allowing greater water absorption.

\subsubsection{Protonic conductivity}

The results of protonic conductivity and thickness can be observed in Table 2 and Figure 6 compared with Nafion ${ }^{\circledR}$. It was observed that the best results were in the membranes MQA02, MQA05, MQB04 and MQB05.

Table 2 Thickness and proton conductivity at $25,40,60$ and $80^{\circ}$ C of chitosan membranes A and B

\begin{tabular}{|l|l|l|l|l|l|}
\hline Membrane & \multicolumn{1}{|c|}{$\begin{array}{c}\sigma \\
\mathbf{2 5} \mathbf{C}\end{array}$} & $\begin{array}{c}\sigma \\
\mathbf{4 0} \mathbf{C}\end{array}$ & $\begin{array}{c}\sigma \\
\mathbf{6 0} \mathbf{C}\end{array}$ & $\begin{array}{c}\sigma \\
\mathbf{8 0}^{\circ} \mathbf{C}\end{array}$ & $\begin{array}{c}\text { Thickness } \\
(\mathbf{p m})\end{array}$ \\
\hline MQA01 & $3,8 \times 10^{-4}$ & $4,5 \times 10^{-4}$ & $4,3 \times 10^{-4}$ & $4,4 \times 10^{-4}$ & $30 \pm 1$ \\
\hline MQA02 & $2 \times 10^{-4}$ & $3,1 \times 10^{-4}$ & $4,3 \times 10^{-4}$ & $3,5 \times 10^{-4}$ & $32 \pm 2$ \\
\hline MQA03 & $2,8 \times 10^{-4}$ & $3,5 \times 10^{-4}$ & $\star$ & $\star$ & $31 \pm 2$ \\
\hline MQA04 & $1,4 \times 10^{-4}$ & $\star$ & $\star$ & $\star$ & $34 \pm 3$ \\
\hline MQA05 & $1,9 \times 10^{-4}$ & $3,9 \times 10^{-4}$ & $8,2 \times 10^{-4}$ & $8,2 \times 10^{-4}$ & $30 \pm 2$ \\
\hline MQBO1 & $4 \times 10^{-3}$ & $1,7 \times 10^{-3}$ & $\star$ & $\star$ & $38 \pm 5$ \\
\hline MQBO2 & $2,8 \times 10^{-3}$ & $3,1 \times 10^{-3}$ & $\star$ & $\star$ & $39 \pm 4$ \\
\hline MQBO3 & $3,9 \times 0^{-3}$ & $\star$ & $\star$ & $\star$ & $45 \pm 1$ \\
\hline MQBO4 & $4,9 \times 10^{-3}$ & $8,2 \times 10^{-3}$ & $1,8 \times 10^{-2}$ & $1,9 \times 10^{-2}$ & $47 \pm 1$ \\
\hline MQBO5 & $9 \times 10^{-4}$ & $6,9 \times 10^{-3}$ & $1,9 \times 10^{-2}$ & $1,6 \times 10^{-2}$ & $25 \pm 1$ \\
\hline
\end{tabular}




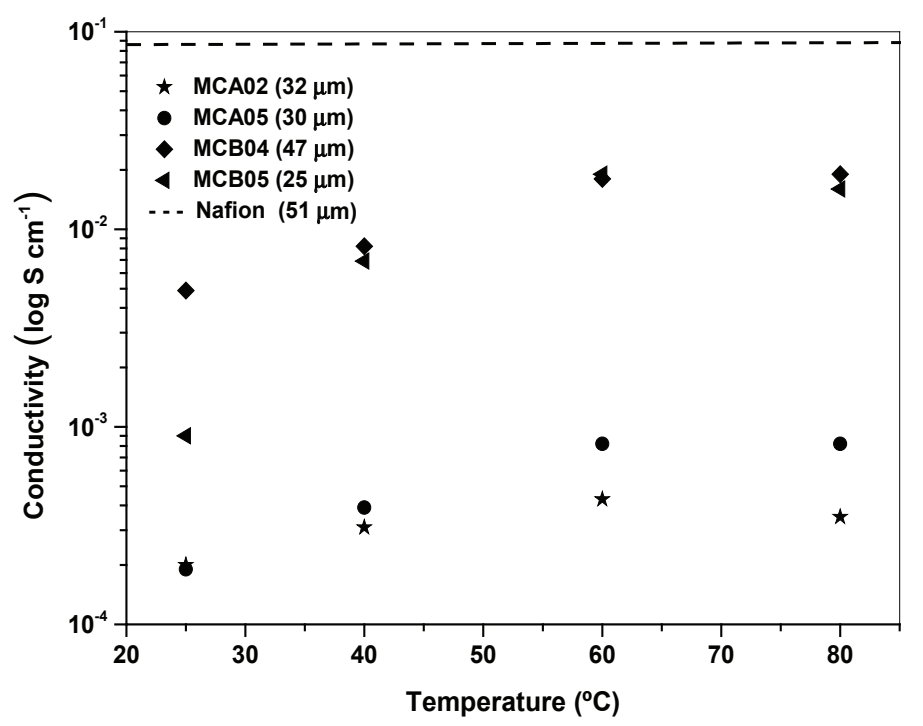

Figure 6 Membranes MQA02, MQA05, MQB04 and MQBO5 compared with Nafion $尺$

The protonic conductivity is inversely proportional to the electrolyte resistance, ie, the higher the resistance, the lower the conductivity. In this sense, the lower impedance values were observed in the Nyquist diagram for membranes MQA02, MQA05, MQB04 and MQB05 as by Fig. 7.
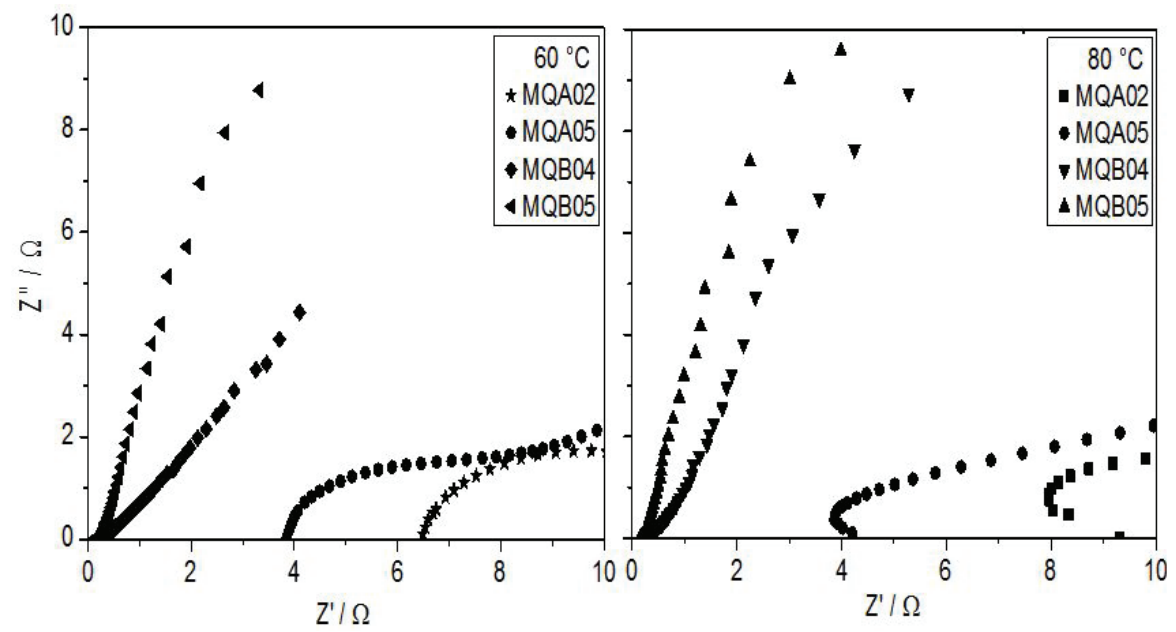

Figure 7 Nyquist diagram

In this, the point used in each graph is the one that appears on the real axis ( $x$ axis) where $Z$ ' is the real membrane resistance $(R)$ and $Z$ " is equal to zero at high frequencies [16]. 
In the case of the MQA series, crosslinking was not favorable to protonic conductivity, because even the best results are still lower than that observed in the MQB series. In this sense, one can say that the difference of DDA and Mm directly influenced the protonic conductivity of the membranes, since higher amounts of $\mathrm{NH} 3$ + groups and the favorable willingness of those in the polymer chain, benefited the transport of protons.

Thus, as seen by Luo et al., (2010) [18], the increase in temperature resulted in higher proton conductivities, which in the case of MQB04 has the same order of magnitude as Nafion ${ }^{\circledR}$ (Figure. 6).

The new results obtained in this study were not found in the literature, because few studies assess the individual properties of chitosan as an electrolyte. Usually these studies use a membrane from commercial chitosan in comparison to their composites, forgetting to check important features.

\section{Conclusion}

The control of conditions for obtaining chitosan in laboratory provided the exploration of a material with characteristics superior to commercial chitosan, resulting in low $\mathrm{Mm}$ and high DDA. The processing employed, directly influenced the protonic conduction of MQBs membranes because the largest number of free amino groups favors the conduction of protons, reaching results even a hundred times larger than the MQAs, reaching the Nafion ${ }^{\circledR}$ order of magnitude, highlight-

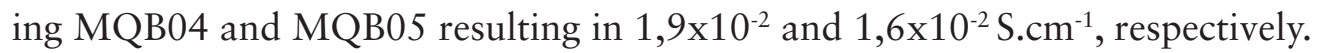

The significant findings of this study, the versatility and the possibility of exploitation and chemical changes in the structure of chitosan, obtained from waste of the shrimp farming activity, makes it attractive for the research and development of proton conductive polymeric membranes with similar or higher performance than Nafion ${ }^{\circledR}$.

\section{Acknowledgements}

The authors thank the Fundação Parque Tecnológico Itaipu - FPTI for the financial support and for granting scholarships for the Notice 058/2014 No. 014/2014 and Mr. Valdecir Antonio Paganini of the University of São Paulo (USP/ IQ), for the protonic conductivity tests.

\section{References}

[1] MALIS J.; MAZÚR, P.; PAIDAR, M.; BYSTRON, T.; BOUZEK, K.; “Nafion 117 stability under conditions of PEM water electrolysis at elevated tempera- 
ture and pressure”, International Journal of Hydrogen Energy, v. 41, Inssue 4, pp. 2177-2188, Jan. 2016.

[2] SMITHA, B.; DEVI, A.; SRIDHAR, S. "Proton-conducting composite membranes of chitosan and sulfonated polysulfone for fuel cell application", International Journal of Hydrogen Energy, v. 33, Inssue 15, pp. 4138-4146, Ago. 2008.

[3] ASSIS, O. B. G. O.; BRITTO, D. de. "Processo básico de extração de quitinas e produção de quitosana a partir de resíduos da carnicicultura", Revista Brasileira de Agrociência, v. 14, n. 1. pp. 91-100, Jan./Mar. 2008.

[4] BESSA-JUNIOR, A. P.; GONÇALVES, A. A. "Análise econômica e produtiva da quitosana extraída do exoesqueleto de camarão”, Actapesca, v. 1, n. 1, pp. 13-28, 2013.

[5] CAMPANA-FILHO, S. P.; BRITTO, D.; CURTI, E.; ABREU, F. R.; CARDOSO, M. B.; BATISTA, M. V.; SIM, P. C.; GOY, R. C.; SIGNINI, R.; LAVALL, R. L. "Extração, estruturas e propriedades de $\alpha$ e $\beta$ quitina", Química Nova, v. 30, pp. 644-650, 2007.

[6] SANTOS, J. E.; SOARES, J. P.; DOCKAL, E. R.; CAMPANA- FILHO, S. P.; CAVALHEIRO, E. T. G. "Caracterização de quitosanas comerciais de diferentes origens”, Polímeros: Ciência e Tecnologia, v. 13, n. 4, pp. 242-249, Oct./Dec. 2003.

[7] TOlaimATE, A.; DESBRIERESB, J.; RHAZIA, M.; AlAGUIC, A. "Contribution to the preparation of chitins and chitosans with controlled physico-chemical properties”, Polymer, v. 44, pp. 7939-7952, Nov. 2003.

[8] KASSAI, M. R. "Calculation of Mark-Houwink-Sakurada (MHS) equation viscometric constants for chitosan in any solvente-temperature system using experimental report viscosimetric constants data", Carbohydrate Polymers, v. 68 , pp. $477-488,2007$.

[9] RIBEIRO, C.; SCHEUFELE, F. B.; ESPINOZA-QUINONES, F. R.; MODENES, A. N.; SILVA, C. M. G.; VIEIRA, M. G. A.; BORBA, C. E. "Characterization of Oreochromis niloticus fish scales and assessment of their potential on the adsorption of reactive blue $5 \mathrm{G}$ dye", Colloids and Surfaces A: Physicochem. Eng. Aspects, v. 482, pp. 693-701, Out. 2015. 
[10] VICENTINI, D. S. "Efeito da incorporação de peneiras moleculares, poli vinil álcool), montmorilonitas e dióxido de titânio em membranas de quitosana”, Doutorado (Tese), Universidade Federal de Santa Catarina, Florianópolis-SC, 2009.

[11] PAGANIN, V. A.; OLIVEIRA, C. L. F.; TICIANELLI, E. A.; SPRINGER, T. E.; GONZALES, E. R. "Modelistic interpretation of the impedance response of a polymer electrolyte fuel cell”, Electrochimica Acta, v. 43, pp. 3761 - 3766, Ago. 1998.

[12] CARPINÉ, D.; DAGOSTIN, J. L. A.; BERTAN, L. C.; MAFRA, M. R. “Development and characterization of soy protein protein isolate emulsion-based edible films with added coconut oil for olive oil packaging: barrier, mechanical, and termal properties", Food Bioprocess Technolgy, v. 8, pp. 1811 1823, Mai. 2015.

[13] ARANTES, M. K.; KUGELMEIER, C. L.; CARDOSO-FILHO, L.; MONTEIRO, M. R.; OLIVEIRA, C. R.; ALVES, H. J. "Influence of the Drying Route on the Depolymerization and Properties of Chitosan", Polymer Engineering and Science, v. 55, inssue 9, pp. 1969-1976, Set. 2015.

[14] AGUIAR, K. R.; BATALHA, G. P.; PEIXOTO, M.; RAMOS, A.; PEZZIN, S. H. "Produção de membranas híbridas zirconizadas de SPEEK/Copolissilsesquioxano para aplicação em células a combustível do tipo PEM", Polímeros, v. 22, n. 5, pp. $453-459,2012$.

[15] LIMA, R. S. C. "Desenvolvimento de Sistemas de Liberação Controlada de Fármacos: Quitosana/Insulina”, Doutorado (Tese), Universidade Federal de Campina Grande, Campina Grande-PB, 2010.

[16] CAMPANA-FILHO, S. P.; SIGNINI, R. "Efeito na desacetilação de quitina”, Polímeros: Ciência e Tecnologia, v. 11, n.4, pp. 169-173, 2001.

[17] PERLES, C. J. "Propriedades físico-químicas relacionadas ao desenvolvimento de membranas de Nafion ${ }^{\circledR}$ para aplicações em células a combustível do tipo PEMFC”, Polímeros: Ciência e Tecnologia, v. 18, n. 4, p. 281 - 288, 2008.

[18] LUO, Z.; CHANG, Z.; ZHANG, Y.; LIU, Z.; LI, J. "Electro-osmotic drag coefficient and proton conductivity in Nafion ${ }^{\circledR}$ membrane for PEMFC”, International Journal of Hydrogen Energy, v. 35, Inssue 7, pp. 3120 - 3124, Abr. 2010. 